DE

M E D I C I N A

T R O P I C A L

$\mathrm{DE}$

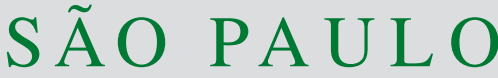

JOURNAL OF THE SÃO PAULO INSTITUTE OF TROPICAL MEDICINE

(1)Fundação Oswaldo Cruz, Instituto Oswaldo Cruz, Laboratório de Microbiologia Celular, Rio de Janeiro, Rio de Janeiro, Brazil

(2) Fundação Oswaldo Cruz, Instituto Oswaldo Cruz, Laboratório de Inovações em Terapias, Ensino e Bioprodutos, Rio de Janeiro, Rio de Janeiro, Brazil

(3)Prefeitura de Benevides, Secretaria Municipal de Saúde, Vigilância Epidemiológica, Benevides, Pará, Brazil

(4) Universidade da Amazônia, Centro de Ciências Biológicas e da Saúde, Belém, Pará, Brazil

${ }^{(5)}$ Instituto Evandro Chagas, Laboratório de Hanseníase, Seção de Bacteriologia e Micologia, Ananindeua, Pará, Brazil

(6) Universidade do Estado do Pará, Centro de Ciências Biológicas e da Saúde, Belém, Pará, Brazil

Correspondence to: Maria Helena Féres Saad

Fundação Oswaldo Cruz, Instituto Oswaldo Cruz, Laboratório de Microbiologia Celular, Av. Brasil, 4365, CEP 21040-360, Rio de Janeiro, RJ, Brazil

Tel: +55 21 2598-4346

Fax: +55 21 2270-9997

E-mail: saad@ ioc.fiocruz.br

Received: 15 February 2017

Accepted: 17 May 2017

\section{Environmental aspects related to tuberculosis and intestinal parasites in a low-income community of the Brazilian Amazon}

\author{
Biatriz Araújo Cardoso ${ }^{1,2}$, Fabio de Oliveira Fonseca ${ }^{2}$, Antonio Henrique \\ Almeida de Moraes Neto ${ }^{2}$, Ana Caroline Guedes Souza Martins ${ }^{3}$, Nissa \\ Vilhena da Silva Oliveira ${ }^{4}$, Luana Nepomuceno Gondim Costa Lima ${ }^{5}$, George \\ Alberto da Silva Dias ${ }^{6}$, Maria Helena Féres Saad ${ }^{1}$
}

\section{ABSTRACT}

We carried out a cross-sectional study from January to December 2015 on 1,425 inhabitants from a floating population in the Brazilian Amazon (Murinin district, Pará State) to describe the population-based prevalence of tuberculosis (TB) from 2011 to 2014, recent TB contacts (rCts) latently infected with Mycobacterium tuberculosis (LTBI), the coverage of the local health network, socio-environmental factors, and frequency of intestinal parasitic infection (IPI). We found that the sanitary structure was inadequate, with latrines being shared with other rooms within the same accommodation; well water was the main source of water, and $48 \%$ of families had low incomes. The average rate of TB was 105/100,000 inhabitants per year; one third of TB patients had been household contacts of infected individuals in the past, and $23 \%$ of rCts were LTBI. More than half $(65 \%)$ of $44 \%$ of the stools examined (representing $76 \%$ of the housing) had IPIs; the highest prevalence was of fecal-oral transmitted protozoa (40\%, Giardia intestinalis), followed by soil-transmitted helminths (23\%). TB transmission may be related to insufficient disease control of $\mathrm{rCts}$, frequent relocation, and underreporting. Education, adopting hygienic habits, improving sanitation, provision of a treated water supply and efficient sewage system, further comprehensive epidemiological surveillance of those who enter and leave the community and resources for basic treatment of IPIs are crucial in combating the transmission of these neglected diseases.

KEYWORDS: Intestinal parasites. Mycobacterium tuberculosis. Tuberculosis. LTBI. Amazon. Neglected communities.

\section{INTRODUCTION}

According to the World Health Organization (WHO), unsanitary living conditions are associated with the increase in the incidence of tuberculosis (TB) and intestinal infections in low-income populations. Without improvements to the environment, sanitation, housing, education and health services, inequalities will be perpetuated and are likely to increase the risk factors as well as the incidence and the prevalence of preventable diseases. The target areas for improvement are among those included in the 17 sustainable development goals (SDGs) adopted by all United Nations member States in the September 2015 Assembly. The SDGs and the End TB Strategy share the common aim of ending the global TB epidemic by the end of $2035^{1}$. The WHO Stop TB Strategy, developed from 2006 to 2015, targets TB control through healthcare and economic partnerships, including curative and preventive approaches to reduce TB prevalence and deaths ${ }^{1}$. In addition 
to minimizing the inequalities between countries and communities with a higher incidence of TB to achieve the WHO Stop TB goals, the early identification of patients, follow-up of household contacts, control of individuals latently infected with Mycobacterium tuberculosis (LTBI) who are at higher risk of developing TB and treatment to reduce mortality from $\mathrm{TB}^{2}$ have also been included.

According to the natural history of TB, $5 \%$ of infected individuals will develop active disease during the first years after infection and another 5\% may remain latently infected and may develop active TB at some point later in life ${ }^{3}$. Therefore, disease control in individuals recently exposed to a TB index case (IC) is an important strategy to help TB control and prevent the onset of LTBI, especially among household and immunosuppressed contacts ${ }^{4,5}$; however, according to the $\mathrm{WHO}^{4}$, fewer than $50 \%$ of cases are assessed and treated preventively.

Unlike TB, intestinal parasitic infections (IPIs) are not reportable; the frequency of IPIs in Brazil is variable in different geographic areas and there is a lack of statistical data showing the real prevalence ${ }^{6,7}$. In one study, the frequency of TB in indigenous communities of Northern Brazil was 14\%, and intestinal parasites such as hookworms and Entamoeba histolytica were prevalent $(75 \%)^{8}$. In another study of HIV-seropositive individuals suffering from persistent diarrhea in the same geographic area, Isospora belli was the most detected protozoan $(32.3 \%)$. In Northeastern Brazil, the most prevalent pathogenic intestinal parasite in children with cancer was Blastocystis hominis $(11.4 \%)$ and in nursery children it was Giardia intestinalis $(27 \%)^{9}$. In studies of school children in Belém, the State capital of Pará, the most frequently found helminths were Trichuris trichiura $(57.6 \%)$, Ascaris lumbricoides (36.4\%), and hookworms $(24.3 \%)^{10}$. In contrast, a higher prevalence $(65.3 \%)$ of helminth infections, mainly from A. lumbricoides, hookworms, and T. trichiura, has been reported in rural communities and in small urbanized settlements with limited sanitation in the Brazilian Amazon ${ }^{11}$. The prevalence of polyparasitism is also high in neglected populations; a prevalence of $12.2 \%$ was reported in Ethiopia ${ }^{12}$ and is higher (56\%) in Brazilian indigenous populations ${ }^{13}$. Moreover, studies show that parasitic infections can influence vulnerability to TB in populations at risk ${ }^{14,15}$.

Maintaining a healthy population is a goal of every government. However, sometimes simple control measures and cost-effective strategies are implemented in large urban centers, small areas can be marginalized, condemning their inhabitants to survive in conditions that are not suitable for social and educational growth, and thereby impoverishing public health ${ }^{6,16}$.
The State of Pará in Northern Brazil, ranks third in the region in the incidence coefficient of TB cases $(30 / 100,000$ inhabitants $)^{17}$, but while there are socio-epidemiological data on the major cities, there are little data on the smaller districts. In a previous interdisciplinary study carried out in the municipality of Benevides by a private university, community health workers and community leaders from different districts, the Murinin district was found to be the most vulnerable and neglected in terms of disease prevention and quality of life ${ }^{18}$. Thus, the aim of this study was to describe the population-based prevalence of TB from 2011 to 2014, the frequency of LTBI, the coverage of the local health network, the socio-environmental factors and the frequency of IPIs in this remote area of the metropolitan region of the Brazilian Amazon.

\section{MATERIALS AND METHODS}

\section{Study area}

The Murinin district is located in the North of Benevides municipality, a metropolitan area of Belém, State capital of Pará. It lies $28 \mathrm{~m}$ above sea level, has an equatorial climate, a geographic area of $32.5 \mathrm{~km}^{2}$, and is accessed by the BR-316 highway and then by the PA-404 State road ${ }^{19}$.

The district has about 5,000 inhabitants, distributed in approximately $1,200^{18} \mathrm{dwellings}$ and is served by two basic healthcare services, the Family Health Unit (FHU) and the Paraíso Health Center (PHC), both of which also provide urgent/emergency care. These services cover four Family Health Strategy (FHS) areas that provide primary care: Murinin 1, Murinin 2, Paraíso 1 and Paraíso 2. According to the National Register of Healthcare Establishments/ Department of Health, the FHU is served by 19 community health agents, two nurses, seven nursing technicians, four family health medical doctors, two agents employed to combat endemic diseases, three dentists, and two dental hygienists. The PHC comprises 16 community health agents, three nurses, 11 nursing technicians, two family health doctors, three general clinical doctors, two agents employed to combat endemic diseases, two dentists, two assistants in oral care, two dietitians, one social worker, one physiotherapist, one occupational therapist, and one psychologist.

The district includes urban and rural areas of occupation, has low socio-economic indicators and poor sanitation and is becoming a dormitory district for the State capital, Belém, where most of the population works. The district's economic activity is centered on the construction, sawmill, and agricultural industries. There are four private and six public schools, three of which are maintained by the State 
and the other three by the municipality. The schools offer primary, intermediate and high school education ${ }^{18}$.

\section{Study population}

The inclusion criteria used to select the sample were diagnosed cases of TB in the Murinin district, according to the mandatory register of the National Notifiable Diseases Information System (SINAN). The criteria for TB diagnosis and treatment were in accordance with those of the Brazilian Ministry of Health ${ }^{20}$. Treatment was free of charge (National Tuberculosis Control Program - PNCT) and administered under direct supervision of qualified local healthcare workers. To assess clinical outcomes of treatment, TB patients diagnosed between 2011 and 2014 were followed up with periodic visits to the patient's homes after being registered in this study (2015/2016). To detect the frequency of LTBIs, recent TB household contacts $(\mathrm{rCt})$ were invited to have a specific blood test for TB infection. The rCt of a TB index case (IC) was deemed eligible for the study if the contact currently resided in the same dwelling as the IC, or had spent more than $6 \mathrm{~h} /$ day in the company of the IC for two consecutive months prior to diagnosis, or had had at least 200 hours of exposure to bacilli ${ }^{21}$. To assess the frequency of IPIs, the inclusion criteria were all TB households; neighboring households in the same and in surrounding streets were also invited to participate in the study. Finally, to characterize the socio-environmental profile, only the lead householder was interviewed however, all residents were registered, without distinction of sex and age. Subjects with neurological problems and with other infectious diseases were excluded.

\section{Georeferencing}

To assess the spatial distribution of TB patients, parasiteinfected individuals, and the extent of FHS coverage in the Murinin area, georeferencing was performed using observations about participants and municipal health documents. The map of the area was built using the open map data sites from Google Maps, United States Geological Survey, Scripps Institution of Oceanography, Landsat, Digital Globe, and TerraMetrics.

\section{Data collection on the socio-economic profile}

To assess the living conditions in Murinin between January and December 2015, we conducted a descriptive cross-sectional survey using selected individuals from the community and non-probabilistic sampling for convenience. From a total of 1,200 households, a non-probabilistic sample of 300 houses was generated ${ }^{22}$; however, we registered 360 households for the study. Data collection was performed by two trained researchers using a structured questionnaire for each householder which was completed by an interviewer. The questionnaire included questions on sex, age, educational level, family income, physical characteristics of the house, sanitation structure, water supply and type of sewage system. Quality assurance procedures included pilot data collection, analyzing the operational strategy used identifying the bottleneck and correcting the method used; additionally, the principal investigator checked the data for completeness soon after collection, as well as for accuracy, clarity, and consistency.

\section{Laboratory procedures}

During the study, after diagnosis of the TB IC, the eligible rCts were recruited for LTBI immunological testing. QuantiFERON@-TB Gold In-Tube (QFT-G) assays were performed, using whole blood of each contact, as described by the manufacturer (Cellestis Ltd., Melbourne, Australia), at the Leprosy Laboratory, Department of Bacteriology and Mycology, Instituto Evandro Chagas, Ananindeua, Pará. The following day, after centrifugation (Vision - Micro High Speed Refrigerated Centrifuge - VS-15000CFN II), the supernatants were collected and stored at $-20{ }^{\circ} \mathrm{C}$ for detection of interferon gamma (IFN- $\gamma$ ) produced by white blood cells. ELISA testing was performed at the Cellular Microbiology Laboratory, Instituto Oswaldo Cruz, Fundação Oswaldo Cruz, using a DuoSet ${ }^{\circledR}$ ELISA kit (R\&D Systems, Abingdon, UK), according to the manufacturer's manual.

Universal stool collectors were identified with the name of the registered participants and delivered to the head of each house, who received a routine explanation about collection and procedure for storage of specimens. The collectors were fetched from the houses within three days after delivery and were transported to the Clinical Laboratory, Hospital Municipal de Mosqueiro, Belém, Pará for processing on the day of arrival at the laboratory. The spontaneous sedimentation method described by Lutz ${ }^{23}$ and Kato-Katz et al. ${ }^{24}$ was used to assess parasitic forms, in accordance with the routine procedure of the public health system in Brazil. Positive cases were referred to the health service for treatment.

\section{Statistical analysis}

Data from questionnaires were entered on Microsoft Excel ${ }^{\circledR}$ (Microsoft Corporation, Redmond, WA, USA) spreadsheets and a descriptive analysis was subsequently 
undertaken. Data were represented as means \pm standard deviations and percentages. The G-test (Grip) and the Chi-square test were used to measure the strength of associations between morbidity and risk factors. We analyzed our results using the GraphPad Prism 5 program (GraphPad Software Inc., San Diego, CA, USA). A p-value $\leq 0.05$ was considered statistical significant. Georeferencing was performed using the QGIS software and a Garmin Dakota ${ }^{\circledR} 20$ GPS system (Garmin Ltd., Chicago, USA), which was marked with 360 points representing the houses registered.

\section{Ethical statement}

The study complied with the ethical requirements recommended by Resolution 466/12 from the Brazilian National Commission of Ethics in Research (CONEP) and was approved by the Ethics Committee of the Amazon Research University (Protocol $N^{\circ}$ 766.312). Informed written consent was obtained from all adult participants and from the parents or legal guardians of minors; the confidentiality of all participants was assured.

\section{RESULTS}

\section{Sociodemographic data}

Data were collected from 360 houses (30\% of all housing in the district), which included 13 houses in which a resident had TB and 347 surrounding houses, comprising 1,425 registered individuals ( $29 \%$ of all inhabitants). Over half the participants were female $(52 \%, 746 / 1,425)$ and in productive adulthood $(730 / 1,425,51 \%$; range $20-59$ years); $22 \%(308 / 1,425)$ were young children $(0-9$ years $)$ and $21 \%(296 / 1,425)$ were older children (10-19 years). It is worth noting the low number of elderly participants (over 60 years) $(6 \%, 91 / 1,425)$. The majority of participants $(70 \%$, 993/1,425) were of mixed ethnicity, and $16 \%(233 / 1,425)$ were African descents.

\section{Socioeconomic data}

From a total of 1,117 participants, about one third of those aged 20-59 years had not completed elementary school, compared with $67 \%$ of older children (10-19 years), of which $49 \%$ were older teenagers (14-19 years), and 58\% were elderly ( $\geq 60$ years). Illiteracy was found in $21 \%$ of the elderly (Table 1 ). The total family income of almost half of the families was equivalent to the minimum wage or less $(48 \%, 172 / 360)$. Of all the families that fulfilled the criteria to receive the government social benefit or "family allowance" (those with dependent children up to 17 years), only $21 \%(115 / 535)$ claimed these benefits; $57 \%$ of the elderly (52/91) received retirement benefits. Among the economically active population, only $7.5 \%(08 / 106)$ worked as junior apprentices (14-17 years) and 63.5\% (521/820) had paid work (18-64 years), as defined by the Institute of Applied Economic Research ${ }^{25}$.

\section{Environmental sanitation}

As shown in Table 2, there was no difference between physical characteristics of houses of TB patients and other houses. The majority of the houses had ceramic/cement/ wood floors $(92 \%)$, and wooden $(38 \%)$ or masonry $(62 \%)$ walls. All had some sanitation, but this often seemed to be inadequate, because, although there were some flushing latrines, they were shared with other rooms in the same house.

Table 1 - Distribution by educational level of the study participants ( $n=1,117$ ), living in the Murinin District, Benevides, Pará, Brazil, in 2015

\begin{tabular}{|c|c|c|c|c|c|c|}
\hline \multirow[t]{2}{*}{ School level } & \multicolumn{2}{|c|}{$\begin{array}{l}\text { Older children } \\
\text { (10-19 years) }\end{array}$} & \multicolumn{2}{|c|}{$\begin{array}{c}\text { Adults } \\
\text { (20-59 years) }\end{array}$} & \multicolumn{2}{|c|}{$\begin{array}{c}\text { Elderly } \\
\text { ( } \geq 60 \text { years) }\end{array}$} \\
\hline & $\mathrm{N}$ & $\%$ & $\mathrm{~N}$ & $\%$ & $\mathbf{N}$ & $\%$ \\
\hline Illiterate & 03 & 02 & 30 & 04 & 19 & 21 \\
\hline Incomplete elementary & 208 & 67 & 235 & 33 & 53 & 58 \\
\hline Elementary & 03 & 02 & 77 & 11 & 03 & 03 \\
\hline Incomplete high school & 62 & 21 & 124 & 18 & 04 & 04 \\
\hline High school & 19 & 07 & 201 & 28 & 06 & 07 \\
\hline Incomplete higher education & 01 & 01 & 22 & 02 & 00 & 00 \\
\hline Higher education & 00 & 00 & 24 & 03 & 01 & 01 \\
\hline Not known & 00 & 00 & 17 & 01 & 05 & 06 \\
\hline TOTAL & 296 & 100 & 730 & 100 & 91 & 100 \\
\hline
\end{tabular}


Table 2 - Physical characteristics of houses of tuberculosis (TB) patients $(n=13)$ and non-TB ( $n=347)$ families, living in Murinin, Benevides, Pará, Brazil, in 2015

\begin{tabular}{|c|c|c|c|c|}
\hline \multirow{2}{*}{ Variables } & \multicolumn{2}{|c|}{ TB } & \multicolumn{2}{|c|}{ Non-TB } \\
\hline & $\mathrm{n}$ & $\%$ & $\mathrm{n}$ & $\%$ \\
\hline \multicolumn{5}{|l|}{ Floors } \\
\hline Ceramic/cement/wood & 12 & 92 & 324 & 93 \\
\hline Rammed earth & 01 & 08 & 23 & 07 \\
\hline \multicolumn{5}{|l|}{ Wall } \\
\hline Wood & 05 & 38 & 82 & 24 \\
\hline Masonry & 08 & 62 & 265 & 76 \\
\hline \multicolumn{5}{|l|}{ Toilets } \\
\hline None & 01 & 08 & 19 & 05 \\
\hline Outside the house without a latrine & 02 & 15 & 40 & 12 \\
\hline Outside the house with a latrine & 01 & 08 & 16 & 05 \\
\hline Inside the house without a latrine & 04 & 31 & 39 & 11 \\
\hline Inside the house with a latrine & 05 & 38 & 233 & 66 \\
\hline \multicolumn{5}{|l|}{ Pit latrine } \\
\hline Yes & 13 & 100 & 261 & 75 \\
\hline No & 00 & 00 & 86 & 25 \\
\hline \multicolumn{5}{|l|}{ Source of water } \\
\hline Well water & 05 & 38 & 191 & 55 \\
\hline Piped water & 08 & 62 & 149 & 43 \\
\hline Other sources (mineral and rain) & 00 & 00 & 07 & 02 \\
\hline
\end{tabular}

In non-TB housing, pit latrines were the main form of sewage disposal, but $25 \%$ of the families did not even have these, and therefore bathrooms outside the home were surrounding sources of contamination. The number of rooms per house was $3.60 \pm 1.64$ and the number of individuals per house was $2.98 \pm 1.99$. The source of water for domestic consumption for most TB families (62\%) was piped water, while, for non-TB families, it was well water (55\%).

\section{Frequency of TB patients and contacts with LTBI}

From 2011 to 2014, 21 TB cases were notified reflecting an average of 5.25 cases per year and an average incidence rate of 105/100,000 inhabitants. Of these, $62 \%(n=13)$, and their rCts, participated in the study and were followed up for 2 years. Although eight new cases were recorded in 2015 and 10 in 2016, these individuals did not participate in the study because it was already in progress. All participants with TB had pulmonary TB, except one with extrapulmonary TB; most were male $(10 / 13,77 \%)$ and the mean age was $32.23 \pm 16.01$ years (range, $5-62$ years). After six months of treatment, the majority (10/13 patients) were cured and one left the district. The remaining two patients abandoned the treatment (15\%), one, after being arrested, remained without specific treatment while the other was an alcoholic patient who died due to multiple organ failure. Of the 13 patients, $11(85 \%)$ were contacts of family members with TB and $45 \%$ (5/11 patients) were household contacts during the active phase of past TB family member; at that time, however, none was clinically evaluated or received preventive treatment for LTBI.

A total of 48 individuals fulfilled the criteria for recent close TB contacts, and they underwent LTBI immune investigation; there was an average of $3.69 \pm 2.05$ individuals per family, a mean age of $26.95 \pm 20.14$ years ( 1 to 80 years), and most contacts were female $(29 / 48,60 \%)$. On testing for LTBI, 11 individuals (23\%) had positive results but none developed active TB during the follow-up period. The local healthcare service, although notified, did not offer clinical evaluation or preventive treatment for these patients because this is not routine practice. It would be helpful if the local health service evaluates the possibility to improve LTBI control in the Murinin District.

\section{Intestinal parasitic infections}

A total of $44 \%(621 / 1,425)$ of the participants, from $217 / 360(60 \%)$ houses, returned stool samples and $65 \%$ 
(402/621), living in 76\% (165/217) of the houses, were parasitized. A significant higher number of individuals in all age groups were found to have more fecal samples infected with intestinal parasites than fecal samples with negative results $(\mathrm{p}<0.03)$ (Figure 1). Polyparasitism was found in $36 \%(145 / 402)$ of the subjects with intestinal parasites, three of whom had four species of parasites and 22 had three species; the other multiple infections comprised mainly two species (120/420).

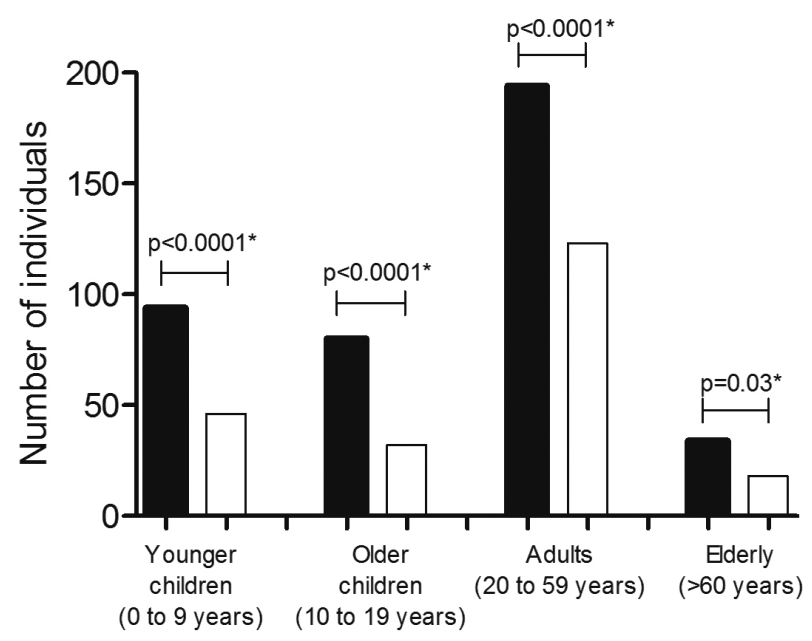

Figure 1 - Distribution of the participants $(n=402)$, infected (black bars) and not infected (white bars) with intestinal parasites, stratified by age. They lived in the Murinin District, Benevides, Pará, Brazil, in 2015. *Chi-square test, $p \leq 0.05$

The frequency of soil-transmitted helminths was $23 \%$ and comprised A. lumbricoides (14\%), Ancylostomidae (4\%), T. trichiura (2.5\%), and Strongyloides stercoralis $(1 \%)$. However, among IPIs caused by protozoa transmitted via the fecal-oral route, Giardia intestinalis was the most prevalent (40\%), followed by E. histolytica (21\%) and B. hominis (14\%). The non-pathogenic helminth Endolimax nana represented $32 \%$ of positive cases and was associated with most multiple infections. G. intestinalis, E. nana, and $E$. histolytica were the most frequently found intestinal parasites (Figure 2). Unfortunately, 90.3\% of infected individuals (363/402) were not treated because of the lack of medicines in the local healthcare system. Therefore, it is necessary to improve public health, focusing more attention on this issue as these drugs are considered basic pharmacy items.

Among TB and LTBI cases, only 6/13 and 6/11 individuals, respectively, returned stools for examination; most samples tested positive ( $\mathrm{n}=4$ and 5 , respectively). Only $8 \%$ of the elderly were infected.

There was no significant association between parasite species and demographic characteristics of the participants or physical characteristics of the houses.

\section{Georeferencing}

In order to map the distribution of the primary healthcare service in the Murinin district, georeferencing was performed. Of the study area, $37 \%$ was covered by FHS areas Murinin 1, Murinin 2, and Paraíso 1 and 28\% was covered by Paraíso 2; however, $35 \%$ of the study area was not covered by any FHS area (Figure 3). The highest number of TB cases occurred in Murinin 1 (5/13 cases, 39\%). Of note, two cases of TB were not officially notified, although they were diagnosed and under treatment. According to the community health agent, these individuals were registered at the local health center so that they could receive medication, but were not registered in the SINAN.

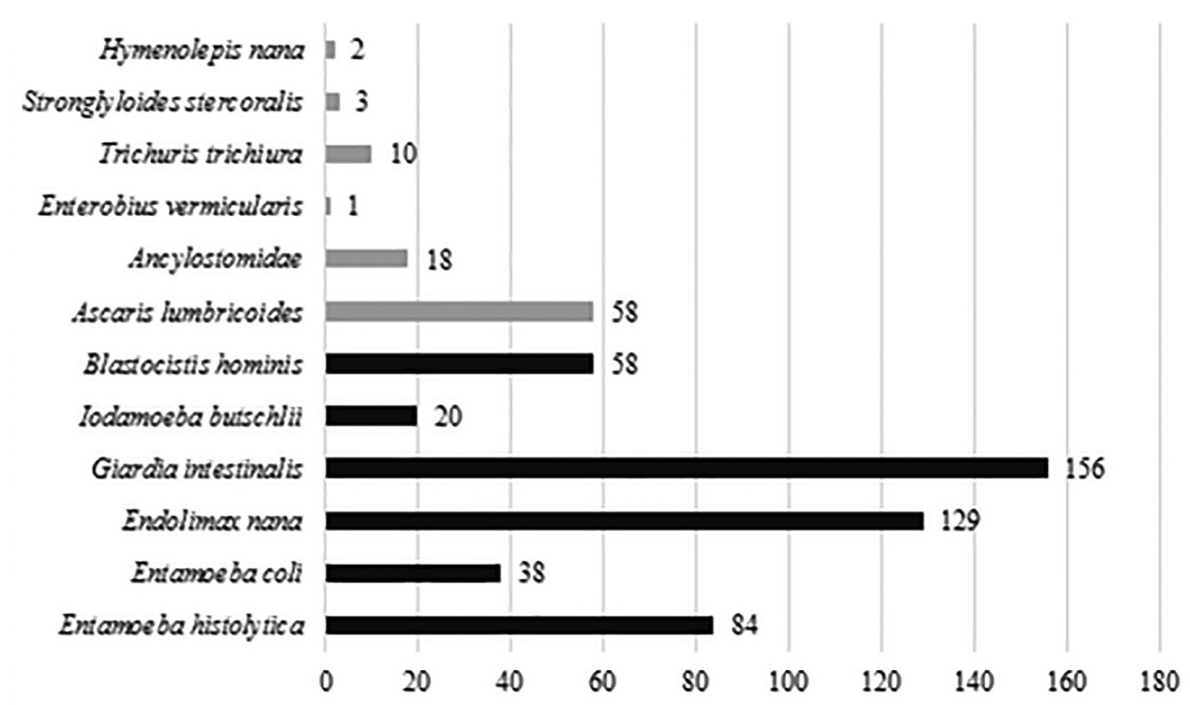

Figure 2 - Distribution of intestinal infections caused by soil-transmitted helminths (gray bar) and fecal-oral transmitted protozoa (black bar) in stools collected in 2015 from the 402 participants' houses in the Murinin District, Benevides, Pará, Brazil 


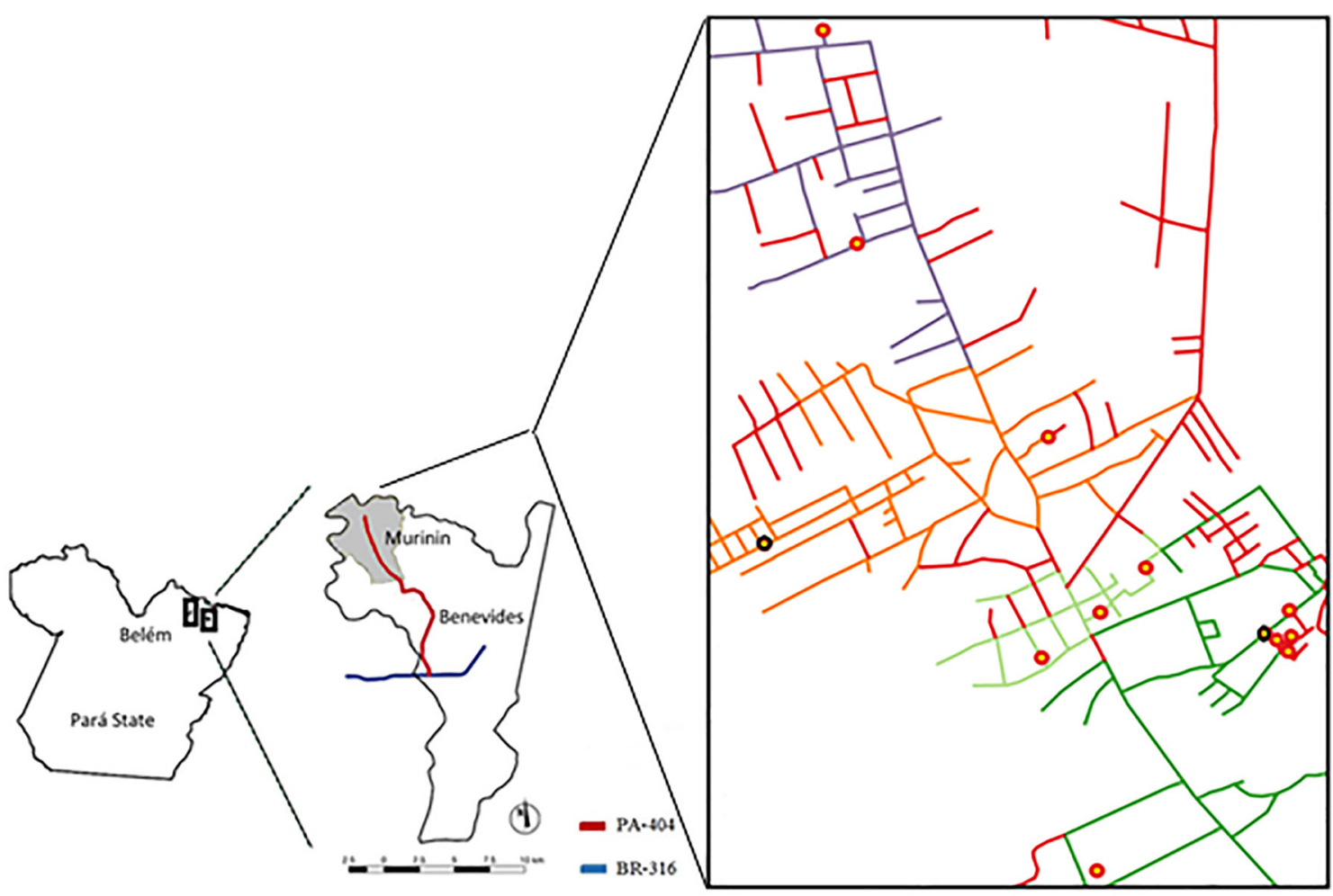

Figure 3 - Location of the Murinin district, Benevides, Pará State, Brazil and schematic representation of the Family Health Strategy (FHS) coverage areas and location of tuberculosis (TB) patients' houses (red circles), District Murinin, Benevides, Pará, Brazil. Dark green: FHS Murinin 1. Light Green: FHS Murinin 2. Orange: FHS Paraíso 1. Blue: FHS Paraíso 2. Red lines: Area inhabited but not covered by any FHS. Black circles: TB cases that were not officially notified

The distribution of IPIs in the FHS areas was significant, as follows: Murinin 1 and Paraíso 2 ( $\mathrm{p}<0.0001$ ), and Paraíso 1 ( $\mathrm{p}=0.0004)$; the highest frequency was in Paraíso 2 (56/76 cases, $73 \%$ ) (Table 3). Among the parasitized individuals, the most common species was $G$. intestinalis in Murinin 1 (62/136 cases, $45.5 \%$ ), Paraíso 2 (20/56 cases, $35.7 \%$ ), and Paraíso 1 (54/165 cases, $32.7 \%$ ), followed by B. hominis in Paraíso 2 (20/58 cases, 34.4\%), Murinin 1 (17/58, 29.3\%), and Paraíso $1(15 / 58,25.8 \%)$.

\section{DISCUSSION}

The process of accelerated and disordered urban growth and poor sanitation in developing countries may result in serious housing and environmental problems, and spread of infectious and parasitic diseases ${ }^{26,27}$. In this study, it was observed that the prevalence of IPIs may be associated with basic sanitation, infrastructure, and housing conditions, factors that also increase the probability of TB infection, as other studies have also found ${ }^{28,29}$. However, environmental interventions are, in general poorly carried out, insufficiently financed by public authorities, generating disagreements and difficulties with other organizations ${ }^{30}$.

The environmental situation in the the Murinin district uncovered in the present study may reflect other similar neglected areas in Brazil ${ }^{6}$. Although $43 \%$ of surveyed households were connected to the public water network, there was often no specific treatment station, with water

Table 3 - Distribution of IPIs according to areas covered by Family Health Unit (FHU), Murinin District, Benevides, Pará, Brazil

\begin{tabular}{|c|c|c|c|c|c|}
\hline \multirow{2}{*}{ FHS } & \multicolumn{2}{|c|}{ Parasitized } & \multicolumn{2}{|c|}{ Non-parasitized } & \multirow{2}{*}{-p-value } \\
\hline & $\mathrm{N}$ & $\%$ & $\mathrm{~N}$ & $\%$ & \\
\hline Murinin $1(n=197)$ & 136 & 69 & 61 & 31 & $<0.0001^{*}$ \\
\hline Murinin $2(\mathrm{n}=77)$ & 45 & 58 & 32 & 42 & 0.17 \\
\hline Paraíso 1 (n=271) & 165 & 60 & 106 & 40 & $0.0004^{\star}$ \\
\hline Paraíso $2(\mathrm{n}=76)$ & 56 & 73 & 20 & 27 & $<0.0001^{*}$ \\
\hline
\end{tabular}

${ }^{*}$ Chi-squared test, $p \leq 0.05$. 
being drawn from collective wells built by the city; moreover, the water supply was not constant. Because of the intermittent supply, residents had to use individual wells. This may have favored the high frequency of IPIs in the area, where Giardia intestinalis is an important contaminant. However, the high prevalence of $G$. intestinalis may even be underestimated, since we examined only a single stool sample per participant; the examination of a series of three stools on alternate days has been shown to improve cyst detection due to intermittent elimination of cysts $^{31}$. Although there is a bias regarding the spontaneous sedimentation method, which is not highly sensitive for larvae detection, Strongyloides stercoralis and Ancylostomidae were found in our population $(>5 \%)$.

The distribution of intestinal parasites in all age groups was significant (Figure 1). This may be explained by the habit of people walking barefoot on contaminated soil and using the pit latrine for bathing especially of children, since most of the time it is the only cemented place near the house. As reported by others, drinking contaminated water, contaminated bath water, lack of personal hygiene and contaminated food have all played a part in contamination by intestinal parasites ${ }^{6}$. Residents in the Murinin district were reported to have toilets inside the house with or without latrines, and some rooms were shared, usually the kitchen and bedrooms; the high frequency of IPIs, including the one caused by the non-pathogenic commensal E. nana, can therefore be attributed to retrocontamination. This interpretation is also supported by the data on the prevalence of $B$. hominis in the parts of the Murinin district covered by the FHS (Figure 3, Table 3). Although the mode of transmission of this protozoan remains unknown, it is quite possible that it is fecal-oral, which is usually related to other pathogens; polyparasitism occurred mainly with G. intestinalis. Therefore, the most plausible explanation is the link between regular consumption and use of unprocessed water. In general, communities tend to focus on chemotherapy for controlling IPIs, but environmental measures, such as the improvement of sanitation and the provision of better sources of water supply, must be the main sustainable public health actions ${ }^{32}$. However, these measures cannot be separated from the adoption of higher standards hygienic practices; therefore, studies to assess the community's knowledge of these issues are needed. Given the prevalence of IPIs and the range of pathogens, we also recommend that, as well as supply basic anti-helminth for the IP-infected population of the Murinin district.

In the Murinin district, $66 \%$ of adults (20-59 years) had low educational levels and $49 \%$ of older children (14-19 years) had not completed the elementary school, all this reflected in the low income of this population.
Thus, improvements in socio-environmental predictors are necessary, but they must also be combined with improvements in the levels of education. It will be very difficult to provide better opportunities to this population, or to any other similar community, without politico-socioeducational measures ${ }^{33,34}$.

The present study corroborates previous assessments of the Murinin district as an area of urban and rural occupation still harboring a community with low socioeconomic indicators and poor sanitation. Moreover, in addition to the high burden of IPIs, we also revealed the continued incidence of TB cases during the study period, despite the fact that the area was provided with healthcare facilities to help TB control. The current strategy of passive detection of already sick individuals by community health agents does not seem adequate. In this small community, our study identified situations that must be avoided, such as the abandonment of treatment, underreporting, areas not officially covered by the FHS, absence of LTBI control, and possible high TB/IPI co-infection, although we could not test all TB patients diagnosed in the study period. Other studies have reported similar data; in one study, only $28.4 \%$ of health professionals assessed TB contacts $^{35}$. There is evidence for IPI-infected individuals co-infected with TB in the Amazonian indigenous population, as well in an urban area in Ethiopia; however, in hospitalized patients in Rio de Janeiro, co-infection was not found ${ }^{8,36,37}$. In a survey carried out in Juiz de Fora, Minas Gerais State, $11.9 \%$ of individuals receiving TB treatment discontinued the treatment, while in our study, the treatment drop-out rate was $15 \%(2 / 13)$, extrapolating the rate recommended by the World Health Organization ${ }^{38}$. Underreporting of cases to the SINAN exceeds $40 \%$ in the State of Rio de Janeiro ${ }^{39}$; we found two unreported cases from the small population of Murinin. Studies on the coverage of the FHS areas indicated that the highest proportion of people living in registered households was found in Tocantins State (93.6\%), followed by Paraíba (81.0\%) and Piauí (80.3\%), and the lowest in the Federal District, which had a coverage of $14.3 \%$. When the analysis was made by regions, the Southeast and North have contributed with the lowest proportions ${ }^{40}$. Therefore, there is still a need for discussion with health services in some areas, including the Murinin district, on how to improve the quality of information on TB.

The findings of our study provide the Municipal Health Secretary of Murinin, Pará State with evidence to improve measures to better control TB. Achieving maximum healthcare coverage is critical in this location, where there is a high population turnover because residents leave their homes to seek job opportunities in other districts, and new residents migrate to the area due to adverse economic conditions in their home districts. New arrivals may have 
come to the area with LTBI, and as the areas adjacent to the Murinin district are also endemic for TB and have poor socio-sanitation conditions therefore favoring the development of active TB. On the other hand, residents also leave the community with the disease favoring the transmission taking place in other locations.

Unhealthy areas with inadequate sanitary conditions favor the proliferation of IPs and studies suggest that these infections may be risk factors for TB development, requiring the simultaneous control of IPIs and $\mathrm{LTBI}^{41}$. In a previous study where the ethnic origin of infected individuals was compared, the rate of illness was high in African descents $(57.5 \%)^{42}$, as was the prevalence of LTBIs among the indigenous population $(76.1 \%)^{36,37}$. Clearly, LTBI control is another approach that must be considered in the Murinin district, as one third of the TB patients diagnosed in the study period were household contacts of TB cases. Thus, improving the detection of LTBI among close TB contacts and providing preventive treatment would help to minimize transmission ${ }^{3,17}$. Additionally, it is important to mention that active TB/LTBI and IP co-infection can lead to an imbalance of the protective immune response to these infections. The characteristic immune response to chronic helminth infection is mediated by type $2 \mathrm{~T}$ helper cells $\mathrm{s}^{43}$. It is possible that this immune response can have a positive impact on the host by modifying the susceptibility to other diseases. Therefore, decreasing the response of type $1 \mathrm{~T}$ helper cell (Th1) to helminth infections regulates the immune response, restricting both, the allergic and the inflammatory processes. However, decreasing the response of Th 2 cells could make the host more susceptible to other clinically important pathologies. The modulation of the immune response to a Th2-type response may negatively influence the response of the Th1 cells, inhibiting the immune protection of the host against pathogens, such as the causative agent of TB, whose protective immune response is Th1-dependent ${ }^{15,16,44}$. All this indicates the need to improve the control of both infections.

This study has some limitations. Not all individuals diagnosed with TB and their contacts agreed to participate; participants were only followed up for a short period of time; we were not able to screen the entire study population for IPIs; and we were unable to obtain detailed data on the hygiene habits of the population. However, our study emphasizes the need for growing communities, such as those belonging to the Murinin District, to have public policies that could minimize the risk factors for the development of active TB and IPIs. Basic sanitation, provision of a treated water supply and efficient sewage system, continued education, more comprehensive epidemiological surveillance for better control of TB patients and LTBIs, and provision of basic treatment for
IPIs are crucial. However, governments must understand the importance of the efficient management of public resources and policies to avoid hindering this process.

\section{ACKNOWLEDGMENTS}

The authors wish to thank Ivete Gadelha Vaz, the Municipal Secretary of Health, and Marlene Mateus, the Municipal Secretary of Environment and Tourism of Benevides (PA), for their overall support; scholarships awarded to the students Letycia Victoria Gomes Pinto, Ana Laura Pureza Pantoja, and Flavia Lobato Maciel; Professor Lorena Ferreira de Amorim from the University of the Amazon for developing the sample collection protocol; the community health agents for their valuable help during the fieldwork- and the residents of Murinin who participated in the study. The study was funded by a grant from the Financiadora de Estudos e Projetos (FINEP), Process $\mathrm{N}^{\circ}$ 01.11.0025.00.

\section{AUTHORS CONTRIBUTIONS}

BAC, MHFS, and AHAMN designed the study; BAC and FOF collected and handled data during fieldwork; BAC wrote the draft of the manuscript; ACGSM contributed to the data collection process; NVSO collected stool samples; LNGCL undertook the immunological analysis; GASD performed the statistical analysis; MHFS supervised the study and wrote and reviewed the manuscript; AHAMN co-supervised the project and reviewed the manuscript. All the authors have reviewed and approved the final version of the manuscript and consented to its publication.

\section{REFERENCES}

1. World Health Organization. Global tuberculosis report 2016. Geneva: WHO; 2016.

2. World Health Organization. The End TB strategy. Geneva: WHO; 2015.

3. Horsburgh CR Jr. Priorities for the treatment of latent tuberculosis infection in the United States. N Engl J Med. 2004;350:2060-7.

4. Dessunti EM, Meier DA, Donath BC, Costa AA, Guariente MH. Infecção latente de tuberculose: adesão ao tratamento e evolução dos casos. Rev Enferm UERJ. 2013;21 esp 2:711-7.

5. Silva AR, Sousa AI, Sant'Anna CC. Barriers in the treatment of latent tuberculosis infection (LTBI) in children: a case study. Esc Anna Nery. 2014;18:386-91.

6. Visser S, Giatti LL, Carvalho RA, Guerreiro, JC. Estudo da associação entre fatores socioambientais e prevalência de parasitose intestinal em área periférica da cidade de Manaus (AM, Brasil). Cien Saude Colet. 2011;16:3481-92. 
7. Moraes Neto AH, Santos CP, Almeida JC. Uma reflexão sobre as parasitoses intestinais em comunidades de baixa renda do norte do Estado do Rio de Janeiro, Brasil. Rev Práxis. 2009;1:71-4.

8. Bóia MN, Carvalho-Costa FA, Sodré FC, Porras-Pedroza BE, Faria EC, Magalhães GA, et al. Tuberculose e parasitismo intestinal em população indígena na Amazônia brasileira. Rev Saude Publica. 2009;43:176-8.

9. Pacheco FT, Silva RK, Mendes AV, Mendonça N, Ribeiro TC, Soares NM, et al. Infecção por Giardia duodenalis e outros enteroparasitos em crianças com câncer e crianças de creche em Salvador, Bahia. Rev Cien Med Biol. 2014;13:280-6.

10. Machado RL, Figueredo MC, Frade AF, Kudó ME, Silva Filho MG, Póvoa MM. Comparação de quatro métodos laboratoriais para diagnóstico da Giardia lamblia em fezes de crianças residentes em Belém, Pará. Rev Soc Bras Med Trop. 2001;34:91-3.

11. Gonçalves AQ, Junqueira ACV, Abellana R, Barrio PC, Terrazas WC, Sodré FC, et al. Prevalence of intestinal parasites and risk factors for specific and multiple helminth infections in a remote city of the Brazilian Amazon. Rev Soc Bras Med Trop. 2016;49:119-24.

12. Elias D, Mengistu G, Akuffo H, Britton S. Are intestinal helminths risk factors for developing active tuberculosis? Trop Med Int Health. 2006;11:551-8.

13. Assis EM, Olivieria RC, Moreira LE, Pena JL, Rodrigues LC, Machado-Coelho GL. Prevalência de parasitos intestinais na comunidade indígena Maxakali, Minas Gerais, Brasil, 2009. Cad Saúde Pública. 2013;29:681-90.

14. Board AR, Suzuki S. The interrelation between intestinal parasites and latent tuberculosis infections among newly resettled refugees in Texas. Int Health. 2016;8:67-72.

15. Elias D, Akuffo H, Britton S. Helminthes could influence the outcome of vaccines against TB in the tropics. Parasite Immunol. 2006;28:507-13.

16. Li XX, Ren ZP, Wang LX, Zhang H, Jiang SW, Chen JX, et al. Coendemicity of pulmonary tuberculosis and intestinal helminth infection in the people's Republic of China. PLoS Negl Trop Dis. 2016;10:e004580.

17. Brasíl. Ministério da Saúde. Secretaria de Vigilância em Saúde. Perspectivas brasileiras para o fim da tuberculose como problema de saúde pública. Bol Epidemiol. 2016;47(13):1-15.

18. Vasconcelos Sobrinho M, Vasconcellos AM, Tavares RM. Universidade enquanto ator do desenvolvimento local: a experiência do Programa Integrado Município Sustentável. In: Horta CE, organizadora. Prêmio Top Educacional Professor Mário Palmério 2011. Brasília: Associação Brasileira de Mantenedoras de Ensino Superior; 2012. p. 49-93.

19. Gomes JN. Condições ambientais e análise social dos moradores do entorno do lixão no município Benevides, Estado do Pará. Caminhos Geogr. 2011;12:305-9.

20. Brasil. Ministério da Saúde. Secretaria de Vigilância em Saúde.
Departamento de Vigilância Epidemiológica. Manual de recomendações para o controle da tuberculose no Brasil. Brasília: Ministério da Saúde; 2011.

21. Brasil. Ministério da Saúde. Secretaria de Vigilância em Saúde. Departamento de Vigilância Epidemiológica. Guia de vigilância epidemiológica. $7^{a}$ ed. Brasília: Ministério da Saúde; 2009.

22. Fontelles MJ, Simões MG, Almeida JC, Fontelles RG. Metodologia da pesquisa: diretrizes para o cálculo do tamanho da amostra. Rev Para Med. 2010;24:57-64.

23. Lutz A. O Schistosomum mansoni e a schistosomatose segundo observações, feitas no Brazil. Mem Inst Oswaldo Cruz. 1919;11:121-55.

24. Katz N, Chaves A, Pellegrino J. A simple device for quantitative stool thick-smear technique in Schistosomiasis mansoni. Rev Inst Med Trop Sao Paulo. 1972;14:397-400.

25. Lameiras MA. Efeitos da população economicamente ativa sobre a taxa de desemprego. Carta Conjuntura. 2013;21:107-14.

26. Brito F. Urbanização, metropolização e mobilidade espacial da população: um breve ensaio além dos números. Brasília: Centro de Planejamento e Desenvolvimento Regional; 2007.

27. Crompton DW, Savioli L. Intestinal parasitic infections and urbanization. Bull World Health Organ. 1993;71:1-7.

28. Lönnroth K, Jaramillo E, Williams BG, Dye C, Raviglione M. Drivers of tuberculosis epidemics: the role of risk factors and social determinants. Soc Sci Med. 2009;68:2240-6.

29. Vieira IC. Expansão urbana, habitações insalubres e a disseminação da tuberculose dos finais do século XIX a meados do século XX em Portugal. Urbana. 2014;6:102-30.

30. Schmidt CW. Linking TB and the environment: an overlooked mitigation strategy. Environ Health Perspect. 2008;116:A47885 .

31. Muniz-Junqueira MI, dos Santos-Neto LL, Tosta CE. Influence of tumor necrosis factor-alpha on the ability of monocytes and lymphocytes to destroy intraerythrocytic Plasmodium falciparum in vitro. Cell Immunol. 2001;208:73-9.

32. Macedo HW, Gonçalves AM, Almeida CB, Dias LV, Muniz MF. Infecção por Blastocystis hominis e Entamoeba histolytica/ Entamoeba dispar em pacientes atendidos em um hospital localizado em Niterói, Rio de Janeiro. Rev Patol Trop. 2010;39:56-62.

33. Pezzi NC, Tavares RG. Relação de aspectos socioeconômicos e ambientais com parasitoses intestinais e eosinofilia em crianças da ENCA, Caxias do Sul - RS. Estudos. 2007;34:1041-55.

34. Menezes RA, Gomes MS, Barbosa FH, Brito GC, Proietii Junior AA, Couto AA. Parasitas intestinais na população residente em áreas úmidas em Macapá, Amapá, Brasil. Rev Biol Cien Terra. 2013;13:10-18.

35. Furlan MC, Gonzales RI, Marcon SS. Desempenho dos serviços de controle da tuberculose em municípios do Paraná: enfoque na família. Rev Gaúcha Enferm. 2015;36:102-10. 
36. Nogueira LM, Basta PC, Teixeira E, Motta MC. Tuberculosis in the Munduruku indigenous group in the Brazilian Amazon: a public health challenge. Rev Patol Trop. 2016;45:23-32.

37. Neto LM, Oliveira RV, Totino PR, Sant'Anna FM, Coelho VO, Rolla VC, et al. Enteroparasitosis prevalence and parasitism influence in clinical outcomes of tuberculosis patients with or without HIV co-infection in a reference hospital in Rio de Janeiro (2000-2006). Braz J Infect Dis. 2009;13:427-32.

38. Pereira JC, Silva MR, Costa RR, Guimarães MD, Leite IC. Profile and follow-up of patients with tuberculosis in a priority city in Brazil. Rev Saude Publica. 2015;49:6.

39. Pinheiro RS, Andrade VL, Oliveira GP. Subnotificação da tuberculose no Sistema de Informação de Agravos de Notificação (SINAN): abandono primário de bacilíferos e captação de casos em outras fontes de informação usando linkage probabilístico. Cad Saude Publ. 2012;28:1559-68.

40. Malta DC, Santos MA, Stopa SR, Vieira JE, Melo EA, Reis AA. Family health strategy coverage in Brazil, according to the National Health Survey, 2013. Cien Saude Coletiva. 2016;21:327-38.
41. Costa MS. Tuberculose e enteroparasitoses: um relato de caso. Rev Panam Infectol. 2016;18:59-62.

42. Brasíl. Ministério da Saúde. Secretaria de Vigilância em Saúde. Detectar, tratar e curar: desafios e estratégias brasileiras frente à tuberculose. Bol Epidemiol. 2015;46(9):1-19.

43. Abate E, Belayneh M, Gelaw A, Idh J, Getachew A, Alemu S, et al. The impact of asymptomatic helminth co-infection in patients with newly diagnosed tuberculosis in north-west Ethiopia. PLoS One. 2012;7:e42901.

44. Resende CT, Hirsch CS, Toossi Z, Dietze R, Ribeiro-Rodrigues R. Intestinal helminth co-infection has a negative impact on both anti-Mycobacterium tuberculosis immunity and clinical response to tuberculosis therapy. Clin Exp Immunol. 2007;147:45-52. 